Original Article

\title{
ORNAMENTAL REPRESENTATIVES OF THE GENUS CENTAUREA L. AS A POLLEN SOURCE FOR BEE FRIENDLY GARDENS
}

\author{
Bożena Denisow* \\ Monika Strzałkowska-Abramek \\ Małgorzata Bożek \\ Anna Jeżak
}

Department of Botany, University of Life Sciences in Lublin
15 Akademicka Street, 20-950 Lublin, Poland

*corresponding author: bozena.denisow@up.|ublin.pl

Received 04 April 2014; accepted 09 September 2014

\begin{abstract}
A bstract
The flowering phenology and pollen production of three ornamental Centaurea species were investigated in the years 2009 and 2012-2013. The study objects, Centaurea montana L. = Cyanus montanus (L.) Hill, Centaurea mollis Waldst \& Kit, and Centaurea dealbata Willd. were cultivated within an area of the UMCS Botanical Garden in Lublin, Poland $\left(51^{\circ} 14^{\prime} \mathrm{N}, 22^{\circ} 34^{\prime} \mathrm{E}\right)$. Under the environmental conditions of SE Poland, the Centaurea species flowered continuously from mid-May to the first week of June. The mass of pollen in anthers was found to be species-related: $3.70 \mathrm{mg}$ (C. montana), $4.02 \mathrm{mg}$ (C. mollis), and $6.01 \mathrm{mg}$ (C. dealbata) per 100 anthers. The total pollen yield was related to the mass of pollen produced in flowers and the abundance of blooming. Pollen grains were medium-sized, spheroid (C. dealbata) or prolato-spheroid ( $C$. mollis and $C$. montana) in shape, and characterized by high viability (over $80 \%$ on average). The pollen provided by the plants of ornamental Centaurea species amounted to $6.0-7.9 \mathrm{~g}$ per $\mathrm{m}^{2}$ on average. The honeybee was the most frequent visitor of $C$. dealbata, accounting for $55.2 \%$ of the total pollinators, and bumblebee species predominated on the flowers of both C. montana (77.7\%) and C. mollis (85.6\%). Solitary bees and dipterans were also observed on the flowers of all species studied, but $C$. mollis was avoided by lepidopterans. Ornamental Centaurea species provide pollen reserves that could support communities of invertebrate pollinators, although the period of effective supply fluctuates annually due to changeable periods of blooming.
\end{abstract}

Keywords: bee pasture, Centaurea dealbata, Centaurea mollis, Centaurea montana, insect visitors, pollen production.

\section{INTRODUCTION}

Habitats for different bee species must consist of rewarding patches of floral resources and suitable nesting sites within the range of their flights (Kearns et al., 1998; Cane, 2001). Forage flora consist of crop plants (Delaplane and Mayer, 2000) and wild species from natural and anthropogenically transformed communities (Wrzesień and Denisow, 2006; 2007; Denisow, 2011). However, due to changes in crop structure and habitat loss or degradation, the value of countryside is decreasing but the value of urban areas, including ornamental gardens, is increasingly being recognized as an important source of food plants supporting a rich diversity of pollinators (Fussell and Corbet, 1992; Denisow and Bożek, 2006; Strzałkowska, 2006; Denisow, 2011; Garbuzov and Ratnieks, 2013). High flora diversity has been recorded among urban green spaces, such as parks, botanical gardens, private ornamental gardens, cemeteries, and railway areas; therefore, these areas are supportive to wild pollinators (Wrzesień and Denisow, 2006). A higher biodiversity of pollinating insects within urban areas compared to countryside was reported recently (Goulson et al., 2010). In Poland, ornamental gardening has become a popular hobby (Fajerski). Beside aesthetic attractiveness, such gardens may contribute to the 
maintenance and/or restoration of insect biodiversity. Because garden plants are often non-native, their usefulness for pollinator-friendly gardens requires observations of phenology, flowering biology and ecology, insect visitors, and the availability of floral reward (Denisow and Bożek, 2006; Strzałkowska, 2006; Masierowska, 2012; Denisow and Strzałkowska-Abramek, 2013). These studies are of great importance as the variation in the total number of insects attracted by ornamental species is broad (80-300-fold) (Garbuzov and Ratnieks, 2013). In Poland, the value of a floral reward from numerous ornamental herbaceous perennials, including species of the families Ranunculaceae, Saxifragaceae, and Malvaceae was highlighted by Denisow and Bożek (2006), Masierowska (2012), and Antoń and Denisow (2014). Ornamental species from the family Asteraceae are considered particularly important magnet plants for insect visitors (Strzałkowska, 2006; Wróblewska and Magacz, 2006; Wróblewska and Stawiarz, 2011). Species from the genus Centaurea have also been considered important (Kołtowski, 2006; Lipiński, 2010). The present study is one of a series of studies on ornamental species to determine the most suitable plants for bee-friendly gardens (Denisow and Bożek 2006; Strzałkowska, 2006; Denisow and StrzałkowskaAbramek, 2013). Here we evaluated the quantity and quality of the pollen of ornamental species from the genus Centaurea that are currently offered in the assortment of gardening centres in Europe, including Poland. In particular, we examined (i) the blooming biology (phenology and duration of pollen presentation), (ii) pollen production, (iii) proportion of pollen grains with protoplasts, and (iv) the spectrum of insect visitors. In addition, pollen grain size was determined, as the feature can be useful for identifying pollen grains by microscopically analysing bee products.

\section{MATERIAL AND METHODS}

Study area and study species. The study was conducted in the years 2009 and 2012 - 2013. The experimental plants were cultivated within an area of the UMCS Botanical Garden in Lublin, Poland $\left(51^{\circ}\right.$ $\left.14^{\prime} \mathrm{N}, 22^{\circ} 34^{\prime} \mathrm{E}\right)$. The following ornamental perennials were included: Centaurea montana L. = Cyanus montanus (L.) Hill, Centaurea mollis Waldst \& Kit, and Centaurea dealbata Willd. The species were grown in the taxonomy section on loess soil at $\mathrm{pH} 6-7$ and fully exposed to the sun. Every year of the study, we used plants derived from the self-renewing popula- tions of the same experimental patches. The species selected for the study were easy to grow and useful in different types of plant arrangements.

C. montana is native to Eurasia, $30-60 \mathrm{~cm}$ tall, tolerates some light shade and drought, and is particularly recommended to be grown on perennial beds and in the light shade of deciduous trees. $C$. mollis is native to Europe, 20 - $40 \mathrm{~cm}$ tall, grows in any soil, is drought- and cold-resistant, and recommended for both ground garden compositions and container gardens. C. dealbata is from the Caucasus range, 80 - $90 \mathrm{~cm}$ height, particularly resistant to drought, and recommended for open spaces in informal gardens, for superb borders, mixed plantings, and cutting gardens (Marcinkowski, 2002).

Blooming observations and foraging of insect visitors. Protocols described by Jabłoński and Szklanowska (1997) and Denisow (2009) were applied. The duration of successive phases of blooming (beginning, full, terminal) was recorded. The beginning of the blooming period was when $10 \%$ of head inflorescences bloomed, the full blooming period consisted of $70-80 \%$ of heads in bloom, and the termination of blooming was when over $85 \%$ of the heads came out of bloom. Due to a long period of blooming, insect visits were monitored for two consecutive days each (i) at the beginning of the full bloom phase, (ii) in the middle of the full bloom phase, and (iii) at the termination of full bloom. The exception was $C$. mollis, for which a 3-day observation was made in 2009. The total number of visiting insects was recorded ( $\mathrm{n}=3-4$ plots; $\left.0.5-1 \mathrm{~m}^{2}\right)$ during each observation period (10 $\mathrm{min}$ at 9.00 , 13.00, and 16.00; GMT + $2.00 \mathrm{~h}$ ).

In order to assess blooming abundance, the number of heads and number of florets per head were counted $(n=18-25)$. Head inflorescences were picked at random from 10 - 25 different plants. The number of flowering stems per $1 \mathrm{~m}^{2}$ plots was also established $\left(n=3-4\right.$ plots; $\left.0.5-1 \mathrm{~m}^{2}\right)$. The data were converted to the number of florets per $1 \mathrm{~m}^{2}$ and the value used to estimate the total pollen output.

Pollen production and quality. The duration of pollen presentation was monitored on 10 - 25 florets from $3-4$ heads for each species. The florets were checked every $2 \mathrm{~h}$ (between 9.00 and 17.00) and the progress in pollen presentation noted. We defined the pollen presentation phase as the time from the beginning of pollen release to the opening of stigma lobes.

The ether method was used to establish the amount of pollen. During each season, well-developed disc 
florets in the bud stage (with closed corolla) were chosen randomly ( $n=20$ - 30). The corolla was carefully separated from the lower ovary using a dissecting needle and the calyx hairs removed. The corolla lobes were opened, and the dissected stamen heads with their filaments removed and placed in a tarred vessel. Each sample contained 50 florets and 250 anthers. Four samples were collected from each species. To enforce the anther dehiscence, vessels with anthers were moved to a dryer (ELCON CL 65) at $33^{\circ} \mathrm{C}$. The pollen was rinsed from the anthers using pure ether $(2 \mathrm{~mL})$ once and $70 \%$ ethanol $(3-4 \mathrm{~mL}$ ) four to five times. The accuracy of the procedure was checked with binocular. Next, the pollen samples were dried and weighed on a WPS 36 electronic balance (RADWAG, Poland). The mass of produced pollen was calculated for the 100 anthers, the head inflorescence, and per unit area (grams per metre squared) by multiplying the relevant data.

Pollen viability ( $n=300$ pollen grains per species) was examined on standard acetocarmine-stained slides, and pollen grain size ( $n=200$ pollen grains per species) was measured on glycerine jelly slides. The length of the polar (P) and equatorial (E) axes of the pollen grain, as well as the P/E ratio, were determined according to Erdtman (1954). Pollen grain observations were made under a light microscope (LM; Nikon Eclipse E-200) at a magnification of $40 \times 10$.

Statistical analysis. Data are presented as means and standard deviation (SD). The Kruskal-Wallis
ANOVA and $\mathrm{H}$-test were used to determine the species and year effect for non-normally distributed data (the number of heads and number of disc florets). A parametric statistical analysis (ANOVA) was applied for the pollen traits (Stanisz, 1996). A post hoc comparison of means was tested using the HSD Tukey's test. The level of significance for all analyses was at $P=0.05$. All analyses were performed using Statistica ver. 6.0 (StatSoft Poland, Krakow).

\section{RESULTS}

Flowering biology and abundance. C. montana was the first to bloom, and was followed by $C$. mollis and by $C$. dealbata (Fig. 1). The duration of blooming differed between the years studied. C. montana bloomed for 29 - 52 days, $C$. mollis for 25 - 28 days, and $C$. dealbata for 31 - 51 days. An exceptionally late spring in 2013 delayed the flowering onset of C. mollis and C. dealbata compared to the flowering times recorded in the previous years.

The species formed a monopodial inflorescence head type. The peripheral florets are ligulate, sterile, and brightly coloured, from blue (C. montana, $C$. mollis) to light-pink ( $C$. dealbata). Pollen is yielded only by the disc florets. The life span of a disc floret was 2 days for $C$. montana and $C$. mollis, and $1-2$ days for $C$. dealbata, on average. The disc florets are protandrous. In the first hours of the life-span, the style extends and pushes through a tube formed by five stamen heads. Pollen released from the

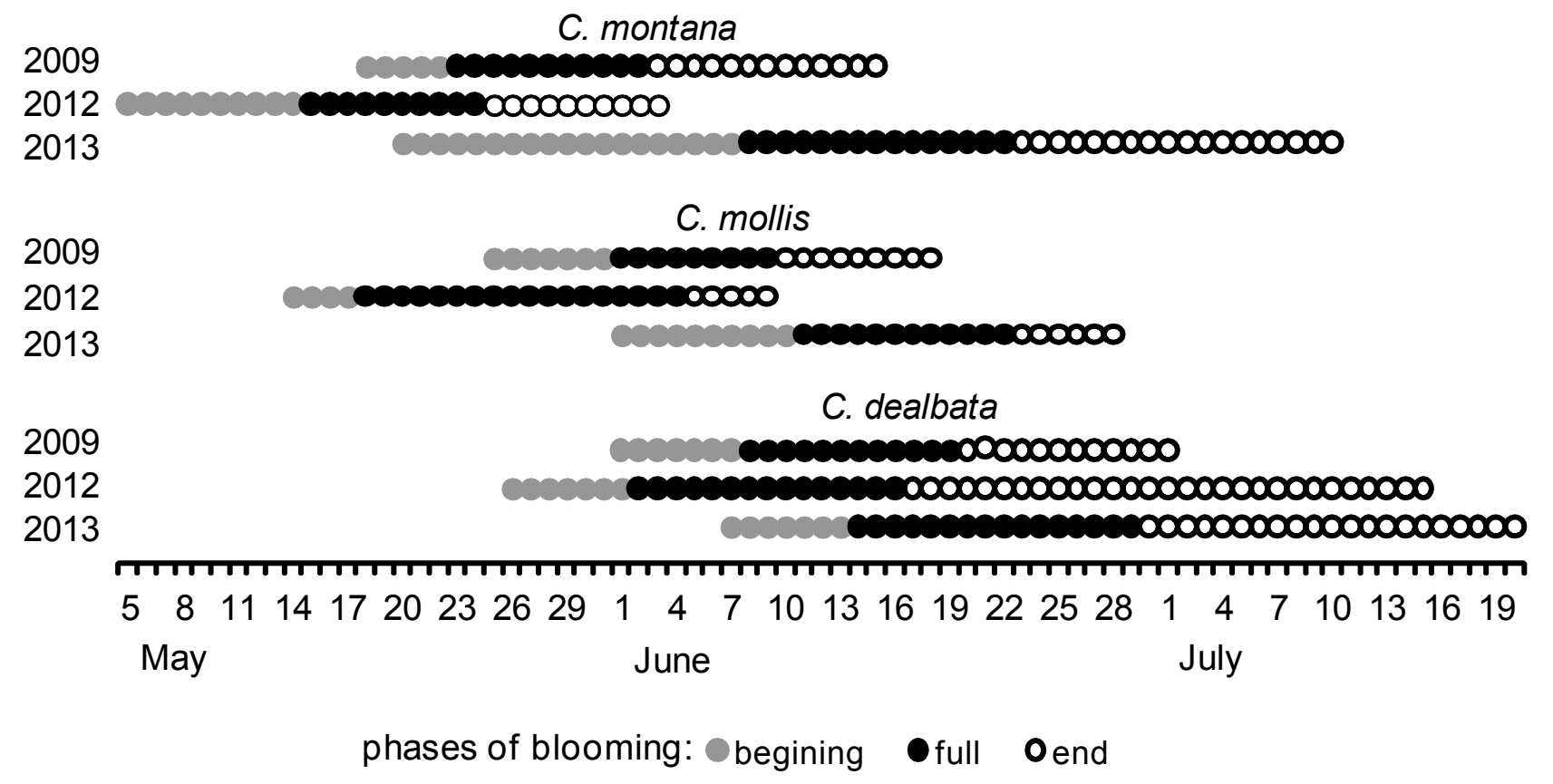

Fig. 1. Time and duration of blooming of Centaurea species in the years 2009 and 2012-2013. 
Table 1.

The number of disc florets developed in heads and the number of heads per $1 \mathrm{~m}^{2}$ for three ornamental species from the genus Centaurea studied in 2009 and 2012-2013

\begin{tabular}{|c|c|c|c|c|c|c|c|c|c|c|}
\hline \multirow{2}{*}{ Species } & \multirow{2}{*}{ Variable } & \multicolumn{2}{|c|}{2009} & \multicolumn{2}{|c|}{2012} & \multicolumn{2}{|c|}{2013} & \multirow{2}{*}{ Mean } & \multirow{2}{*}{ \pm SD } & \multirow{2}{*}{ P-value } \\
\hline & & Mean & $\pm S D$ & Mean & $\pm S D$ & Mean & $\pm S D$ & & & \\
\hline \multirow{2}{*}{ C. montana } & $\begin{array}{l}\text { disc florets } \\
\text { per head }\end{array}$ & 35.4 & 3.3 & 37.8 & 5.0 & 40.8 & 5.9 & 37.9 & 5.0 & 0.148 \\
\hline & heads $\cdot \mathrm{m}^{-2}$ & 126.5 & 21.1 & 80.8 & 11.6 & 76.5 & 20.9 & 94.5 & 28.8 & 0.024 \\
\hline \multirow{2}{*}{ C. mollis } & $\begin{array}{l}\text { disc florets } \\
\text { per head }\end{array}$ & 25.8 & 3.8 & 26.5 & 4.0 & 34.4 & 6.3 & 30.4 & 6.6 & 0.009 \\
\hline & heads $\cdot \mathrm{m}^{-2}$ & 182.0 & 27.7 & 93.8 & 11.5 & 67.5 & 16.6 & 114.4 & 54.2 & 0.012 \\
\hline \multirow{2}{*}{ C. dealbata } & $\begin{array}{l}\text { disc florets } \\
\text { per head }\end{array}$ & 39.4 & 4.0 & 39.8 & 8.1 & 38.0 & 2.9 & 39.9 & 4.7 & 0.792 \\
\hline & heads $\cdot \mathrm{m}^{-2}$ & 70.0 & 14.2 & 76.0 & 17.5 & 55.5 & 17.2 & 66.0 & 17.3 & 0.174 \\
\hline
\end{tabular}

significant effects based on the Kruskal-Wallis test are in bold; SD - standard deviation.

Table 2.

Pollen production and viability of three ornamental Centaurea species

in the years 2009 and $2012-2013$

\begin{tabular}{|c|c|c|c|c|c|c|c|c|c|c|}
\hline \multirow{3}{*}{ Species } & \multirow{3}{*}{ Year } & \multirow{2}{*}{\multicolumn{3}{|c|}{ Pollen per 100 anthers (mg) }} & \multicolumn{4}{|c|}{ Pollen production } & \multirow{2}{*}{\multicolumn{2}{|c|}{$\begin{array}{c}\text { Viability } \\
(\%)\end{array}$}} \\
\hline & & & & & \multicolumn{2}{|c|}{ Per head (mg) } & \multicolumn{2}{|c|}{$\mathrm{g} \cdot \mathrm{m}^{-2}$} & & \\
\hline & & Min - max & Mean & $\pm \mathrm{SD}$ & Mean & $\pm \mathrm{SD}$ & Mean & $\pm \mathrm{SD}$ & Mean & $\pm S D$ \\
\hline \multirow{4}{*}{ C. montana } & 2009 & $4.10-5.30$ & $4.78_{b}$ & 0.50 & $8.46_{b}$ & 0.88 & 10.68 & 1.12 & 99.6 & 0.7 \\
\hline & 2012 & $2.50-3.20$ & 2.90 & 0.32 & 5.47 & 0.60 & 4.42 & 0.48 & 92.6 & 2.6 \\
\hline & 2013 & $3.47-4.10$ & $3.42_{a}$ & 0.51 & $6.98_{a}$ & 1.04 & 5.34 & 0.80 & 94.6 & 1.6 \\
\hline & Mean & & $3.70_{A}$ & 0.88 & $6.977_{A}$ & 1.43 & 6.81 & 2.98 & 95.6 & 3.5 \\
\hline \multirow{4}{*}{ C. mollis } & 2009 & $3.10-4.20$ & $3.63_{\mathrm{a}}$ & 0.48 & 4.68 & 0.62 & 7.99 & 1.06 & 99.0 & 1.7 \\
\hline & 2012 & $3.00-5.10$ & $4.13_{a}$ & 0.90 & $5.47_{b}$ & 1.19 & 5.12 & 1.11 & 98.2 & 1.0 \\
\hline & 2013 & $3.33-5.40$ & $4.32_{\mathrm{a}}$ & 1.01 & $7.42_{c}$ & 1.73 & 5.01 & 1.17 & 96.6 & 2.1 \\
\hline & Mean & & $4.02_{A}$ & 0.77 & $5.85_{A}$ & 1.59 & 6.04 & 1.76 & 97.9 & 1.8 \\
\hline \multirow{4}{*}{ C. dealbata } & 2009 & $4.60-6.50$ & 5.48 & 0.88 & $10.80_{a}$ & 1.74 & 7.56 & 1.22 & 78.3 & 3.3 \\
\hline & 2012 & $5.90-6.87$ & $6.51_{b}$ & 0.44 & $12.94 a$ & 0.88 & 9.83 & 0.67 & 86.6 & 2.7 \\
\hline & 2013 & $6.00-5.90$ & $6.05_{b}$ & 0.13 & $11.50_{\mathrm{a}}$ & 0.25 & 6.38 & 0.14 & 84.6 & 3.3 \\
\hline & Mean & & $6.01_{B}$ & 0.65 & $11.74_{B}$ & 1.32 & 7.92 & 1.66 & 83.2 & 4.6 \\
\hline
\end{tabular}

Means followed by the same small letter are not significantly different between years within species, and followed by the same capital letter are not different among species, according to the Tukey HSD test; SD - standard deviation.

anthers is presented on the stylar trichomes to the insect visitors. Pollen exposition under sunny and dry weather conditions lasts only 3 - 4 hours. The number of disc florets per head is species-related (Kruskal-Wallis test: $\mathrm{H}=3.29, \mathrm{P}=0.012 ;$ Tab. 1 ) and was lowest for $C$. mollis (mean $=30.4)$. $C$. montana and $C$. dealbata produced more disc florets, 37.9 and 39.9 per head on average, respectively. The development of all pollen-yielding florets in the head inflorescence lasted 3 - 4 days for $C$. mollis and
4 - 5 days for $C$. montana and $C$. dealbata.

C. montana and C. mollis developed one-headed shoots, whereas shoots of $C$. dealbata produced 2 - 3 heads. The number of heads per $1 \mathrm{~m}^{2}$ plot depended on the species $(H=6.43, P=0.044)$. The lowest average number of heads (66.0) was noted for $C$. dealbata. Within a species, an effect of year was found for the number of head inflorescences. Each species studied produced the lowest number of heads in 2013, when the winter was severe, spring 
Table 3.

Morphological characteristics of pollen grains

from three ornamental Centaurea species in 2012 and 2013

\begin{tabular}{|c|c|c|c|c|c|c|c|c|}
\hline \multirow{3}{*}{ Species } & \multirow{3}{*}{ Year } & \multicolumn{6}{|c|}{ Length of axis $(\mu \mathrm{m})$} & \multirow{3}{*}{$\begin{array}{c}\text { Shape } \\
\text { index } P / E\end{array}$} \\
\hline & & \multicolumn{3}{|c|}{ Polar (P) } & \multicolumn{3}{|c|}{ Equatorial (E) } & \\
\hline & & Min-max & Mean & $\pm \mathrm{SD}$ & Min-max & Mean & $\pm \mathrm{SD}$ & \\
\hline \multirow{3}{*}{ C. montana } & 2012 & $45.0-52.5$ & 47.5 & 1.8 & $38.8-46.3$ & 42.9 & 1.8 & 1.1 \\
\hline & 2013 & $40.3-50.5$ & 47.2 & 1.1 & $40.5-45.0$ & 42.6 & 1.1 & 1.1 \\
\hline & Mean & & 47.4 & 1.6 & & 42.8 & 1.6 & 1.1 \\
\hline \multirow{3}{*}{ C. mollis } & 2012 & $45.0-51.3$ & 47.8 & 1.7 & $35.0-48.8$ & 42.8 & 2.5 & 1.1 \\
\hline & 2013 & $45.3-51.3$ & 47.8 & 1.5 & $40.0-47.5$ & 43.0 & 2.1 & 1.1 \\
\hline & Mean & & 47.8 & 1.6 & & 42.8 & 2.4 & 1.1 \\
\hline \multirow{3}{*}{ C. dealbata } & 2012 & $35.6-42.6$ & 38.5 & 1.7 & $38.3-40.1$ & 39.5 & 0.8 & 1.0 \\
\hline & 2013 & $36.3-39.1$ & 37.9 & 1.0 & $37.5-40.0$ & 38.9 & 1.1 & 1.0 \\
\hline & Mean & & 38.3 & 1.5 & & 39.2 & 1.0 & 1.0 \\
\hline
\end{tabular}

SD - standard deviation.
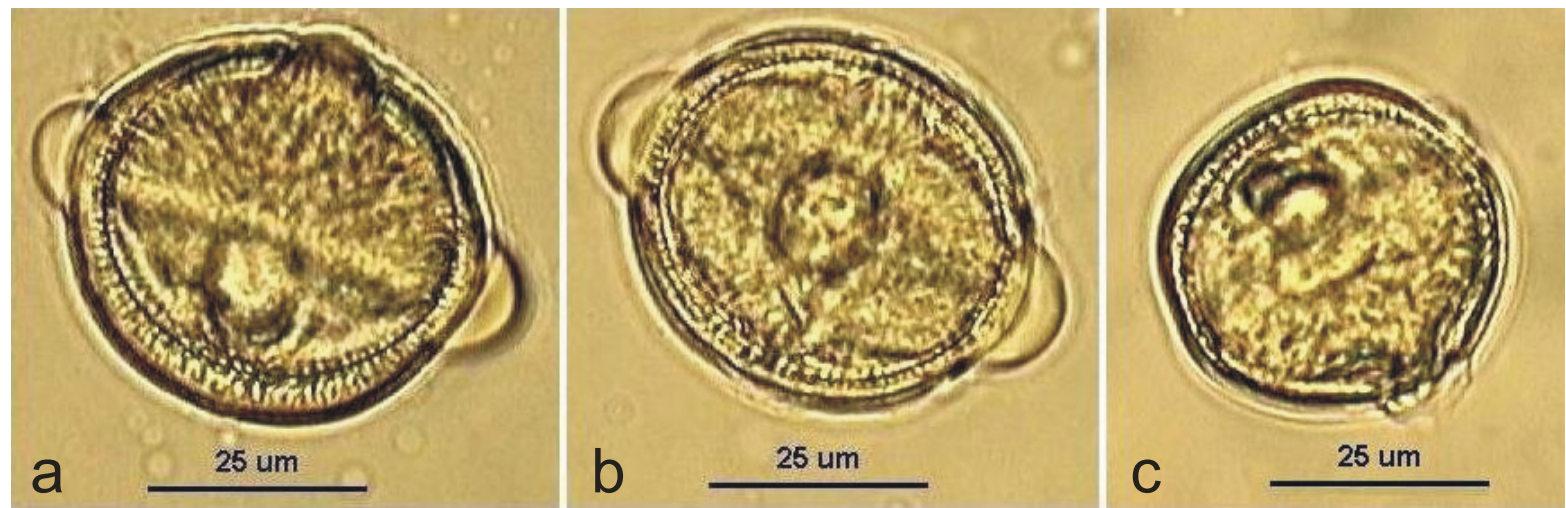

Fig. 2. Light micrographs of pollen grains in equatorial view a. Centaurea montana, b. C. mollis, c. C. dealbata.

delayed, and prolonged drought noted at the end of May and beginning of June.

Pollen production and quality. The mass of pollen in anthers was found to be species-related (Tukey's test: $F_{2,33}=28.781, P<0.001$; Tab. 2). The highest amount of pollen, an average of $6.01 \mathrm{mg}$ per 100 anthers, was yielded by the anthers of $C$. dealbata. The amount of pollen produced in the anthers of C. mollis and C. montana was $30-40 \%$ lower than that of $C$. dealbata. Year-to-year variation was noted in the amount of pollen produced for $C$. montana $\left(F_{2,12}=2.14, P=0.033\right)$ and $C$. mollis $\left(F_{2,12}=1.92\right.$, $P=0.014)$. The pollen production in the anthers of C. mollis was very stable across growing seasons $\left(F_{2,12}=9.14, P=0.261\right)$. The pollen provided by the plants of ornamental Centaurea species was 6.0 -
$7.9 \mathrm{~g}$ per $\mathrm{m}^{2}$ (Tab. 2). The pollen grain characteristics are presented in Table 3 and Figure 2. The pollen grains of $C$. dealbata were spheroid (shape index 1.0), whereas $C$. mollis and $C$. montana pollen grains were prolato-spheroid (shape index 1.1). The pollen grains were characterized by high protoplast content. In all study years, the viability of $C$. mollis and $C$. montana exceeded $90 \%$, but the pollen viability for $C$. dealbata was substantially lower (mean $=83.2 \%$ ).

Insect visitors. The honeybee was the most frequent visitor of $C$. dealbata, accounting for $55.2 \%$ of total visitors (Fig. 3). Bumblebee species predominated on the flowers of both C. montana $(77.7 \%)$ and C. mollis (85.6\%). Solitary bees were also observed on the flowers of all species studied. C. dealbata was also foraged by lepidopterans and dipterans. 

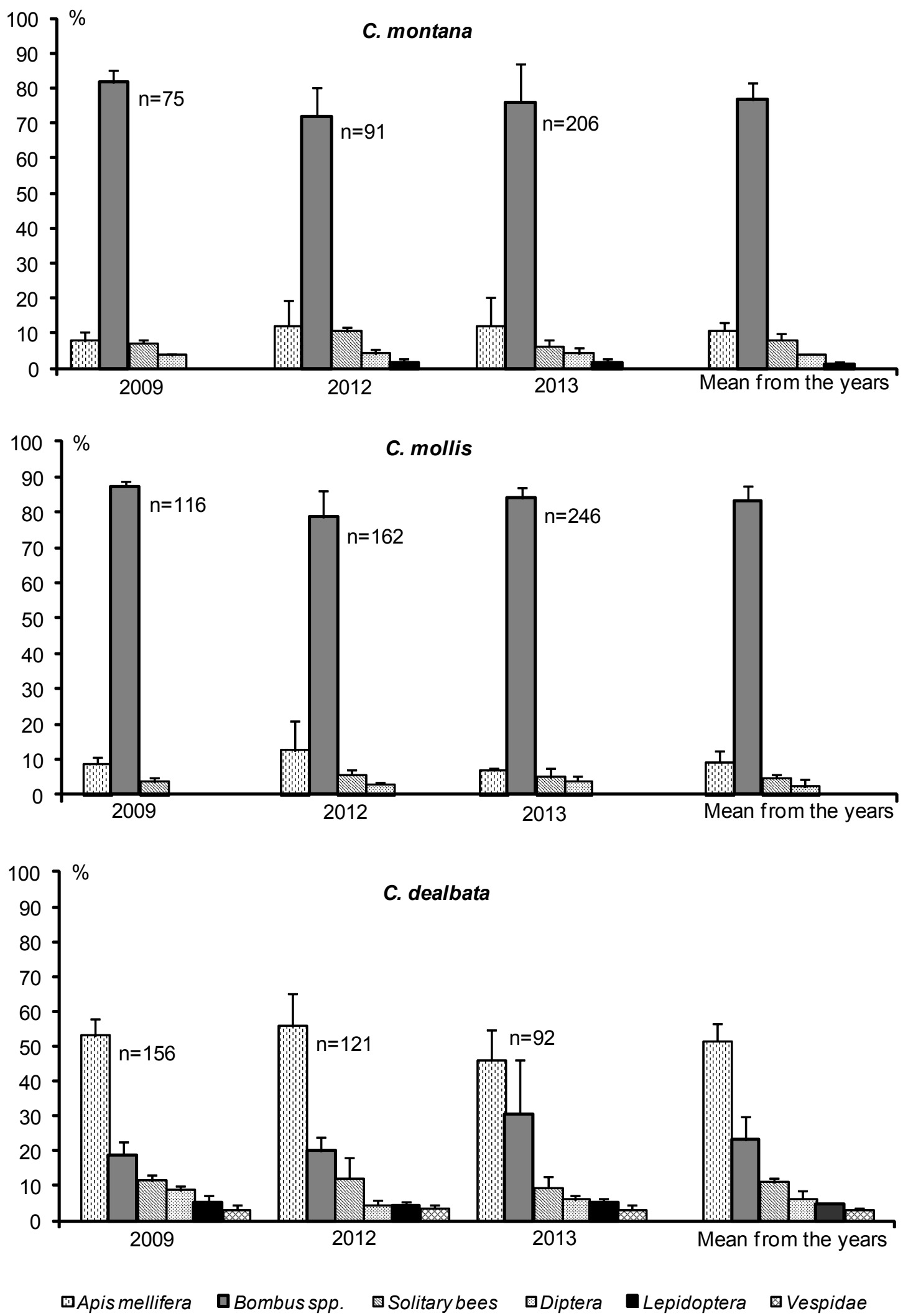

Fig. 3. The percentage participation of insect visitors on flowers of three ornamental Centaurea species. Mean values for the years of study are given; $\mathrm{n}=$ the total number of insect visitors recorded, vertical bars indicate \pm SD. 


\section{J. APIC. SCL. VOL. 58 NOV. 22014}

\section{DISCUSSION}

The results concerning the flowering, pollen production, and insect visitors of the studied ornamental Centaurea species have not previously been reported in the literature. Our study can be considered to contribute to the lists of garden plants that attract insect visitors with floral reward. If planted together in flowerbeds, the species will provide pollen from the first week of May (C. mollis) until mid-July ( $C$. dealbata) during the period of intensive activity among different visiting insects. However, the flowering phenology of the studied ornamentals differed considerably among growing seasons, indicating that these species are sensitive to abiotic factors, mainly different weather patterns over the years of the study. The influence of meteorological factors, including air temperature and precipitation level, on the onset, duration, and abundance of flowering has been described for different taxa (Jabłoński and Szklanowska, 1997), including species from the genus Centaurea occurring in natural habitats in Poland (Denisow, 2006).

In the present study, the mass of pollen produced in the anthers of $C$. dealbata was 1.2 to 2.0 -fold higher than that of $C$. mollis or $C$. montana. As reported by Denisow (2009; 2011), the mass of pollen produced is a highly genetic-dependent trait and may vary greatly among species, even within the same genera. In addition, two out of three species studied exhibited significant year-to-year differences in the mass of pollen produced, which indicates that microsporogenesis and pollen production in $C$. mollis and $C$. montana are sensitive to external factors (e.g., temperature drops or shortage of precipitation). Otherwise the process of pollen production in C. mollis is less responsive to the environment. Differences in species tolerance to habitat conditions with respect to pollen production were demonstrated previously for Asteraceae species (Denisow, 2006; Czarnecka and Denisow, 2014). Similarly, any factors that affect the nutritional status of a plant may affect the amount and quality of pollen produced.

In ornamental Centaurea species, pollen is provided exclusively by tubular disc florets. Mature pollen is released from the anthers and pushed outside the staminal tube by the style, which elongates rapidly at the beginning of male-phase. The pollen is then presented for insects on the style trichomes. This mechanism of pollen presentation is known as secondary pollen presentation (SPP) and is characteristic of the Asteraceae species (Denisow, 2006;
Czarnecka and Denisow, 2014); it has also been observed in other ornamentals, including Solidago $x$ hybrida (Strzałkowska, 2006), Zinnia elegans (Wróblewska and Magacz, 2006), and Ligularia species (Wróblewska and Stawiarz, 2011).

The mass of pollen produced per plant and per unit area was found to be directly related to the abundance of blooming. The number of flowers or inflorescences is the major predictor of pollen yield in many species, including Ranunculaceae (Denisow and Bożek, 2006), Euphorbiaceae (Denisow, 2009), and Asteraceae (Denisow, 2006; Strzałkowska, 2006; Wróblewska and Stawiarz, 2011; Czarnecka and Denisow, 2014). Year-to-year variations in the number of head inflorescences developed by particular Centaurea species affected the fluctuation in the total mass of pollen available to insect visitors. However, we observed that Apoidea foraged for both pollen and nectar despite the fluctuations in blooming abundance.

Pollen grains of the Centaurea species are medium in size, within a range of 25 - $50 \mu \mathrm{m}$ (Erdtman, 1954). According to Jafari and Ghaubarian (2007), four shape groups are distinguished for Centaurea species. The mean shape index of the studied ornamental Centaurea species ranged between 1.0 and 1.1, which classifies the pollen grains as spherical (shape index 1.0) or prolate-spherical (shape index 1.01 - 1.13).

The pollen production values in the present study were higher than those established for Centaurea cyanus (1.4 g per $1 \mathrm{~m}^{2}$ ) but lower that those estimated for Centaurea scabiosa (28.3 g per $1 \mathrm{~m}^{2}$ ) (Denisow, 2006). Therefore, we assume that the studied ornamental Centaurea may be placed among good pollen-yielding plants. However, while choosing the species for pollinator-friendly gardens, we have to consider that only approximately $40 \%$ of the pollen contained in flowers is accessible to feeding insects (Schlindwein et al., 2005). We also have to take into account the nutritional requirements of bees, which differ among species (Müller et al., 2006), and the nutritional value of pollen, which depends on the type of plant (Denisow, 2011). On average, one bee larva may need the pollen from 7 - 1100 flowers (0.9 - 4.5 head inflorescences) for sufficient growth (Müller et al., 2006). Thus, the studied ornamentals may feed 21 - 104 larvae (C. montana), 25 - 126 larvae (C. mollis), or 14 - 73 larvae (C. dealbata). Although the proportion of pollen grains with protoplasts varied significantly among the Centaurea species studied and among the years of study within species, it was 
high on average. According to Roulston et al. (2000), the changeable quality of pollen may potentially contribute in different ways to pollinator diet and fitness, but if the proportion of pollen with protoplasts is $>80 \%$, it supplies important nutritional resources for feeding insects. Moreover, the pollen of the Asteraceae species is considered to be particularly important for entomofauna due to its high caloric value, which is related to the relatively high starch and fat content, a feature that is known to be highly phylogenetically constant (Petanidou and Vokou, 1990).

Among the notable results of the current study is the pattern of insect visitors. The majority of visitors to $C$. montana and $C$. mollis were bumblebee species $(77.7 \%$ and $85.6 \%$, respectively), whereas honeybees predominated (55.2\%) on the flowers of $C$. dealbata, and a variety of other foragers were present. Interestingly, we observed similar groups of insect visitors attracted to ornamental Centaurea species between the years of study. Some of the noted differences may be due to temporal variations in the presence of flower-visiting insect populations, which is a common phenomenon (Goulson, 1999; Masierowska, 2012; Zych and Stpiczyńska, 2012). A repeatable year-to-year pattern of foragers indicates that specific features of the species impacted the preferences of visitors. An analogous situation, a strong repeatable year-to-year pattern of insect visitors but with considerable disparities in foragers among Centaurea species ( $C$. cyanus, C. stoebe, and C. scabiosa) occurring in the natural habitats, was reported by Denisow (2006). Presumably, the disc floret morphology restricted bumblebees to the flowers of $C$. montana and C. mollis. The mean corolla tube length of $7.2 \mathrm{~mm}$ was experimentally shown to be a disadvantage to honeybees (mean tongue length $6.6 \mathrm{~mm}$ ) vs. bumblebees (mean tongue length $7.8 \mathrm{~mm}$ ) (Balfour et al., 2013). Visitor preferences may also be due to the characteristics of the floral reward offered, including nectar features such as sugar composition (Carlson and Harms, 2006; Antoń and Denisow 2014) and pollen features such as starch content (Denisow, 2011). In the case of ornamental Centaurea species, these characteristics require further exploration.

Notably, a broad array of visitors, not only Apoidea bees, was observed on $C$. dealbata. In addition to reward accessibility, this observation may be due to the period and duration of blooming. For example, the onset of flowering of $C$. dealbata occurred later in the season than other Centaurea species. The colour of ray florets (pink in $C$. dealbata vs. blue in $C$. mollis and C. montana) may also impact the frequency of insect visitors. In fact, we observed visits by butterflies, more frequently to the pink flowers of C. dealbata, as strong preferences for flower colour (Pohl et al., 2011). Ornamental Centaurea species, mainly $C$. dealbata, were attractive to dipterans, which have been documented to be primary pollinators for many plant species in terrestrial ecosystems (Zych, 2007), crop plants (Klein et al., 2007), and whose zoophagous larvae play a major role in biocontrol, such as eating crop-damaging aphids (Ssymank et al., 2008). Therefore, we can assume that Centaurea species may indirectly support the pollination service of plants in small home gardens, or even prevent aphid outbreaks.

It is preferable to grow native plants in any kind of bee-pasture gardens (Fussell and Corbet, 1992; Szklanowska and Denisow, 1999; Delaplane and Mayer, 2000). However, as ornamental gardening progresses, different non-native plants will be popular and used. These species provide pollen reserves that could support communities of invertebrate pollinators, although the period of effective blooming fluctuates annually.

\section{CONCLUSIONS}

Under the environmental conditions of SE Poland, the ornamental Centaurea species flower continuously from mid-May to the first week of June, and the species support the floral resources mainly for honeybees ( $C$. dealbata), bumblebees ( $C$. montana and $C$. mollis), and solitary bees, dipterans, and lepidopterans.

Ornamental Centaurea species should be considered when creating multi-flower gardens that allow bees to forage on good quantity and quality pollen.

\section{ACKNOWLEDGEMENTS}

We are grateful to Dr. hab. Anna Wróblewska, Prof. UP, and Dr. Ernest Stawiarz for the possibility of microphotographic documentation. We would also like to thank two anonymous reviewers for their valuable comments on an earlier version of the manuscript.

\section{REFERENCES}

Antoń S., Denisow B. (2014) Nectar production and carbohydrate composition across floral sexual phases: contrasting patterns in two protandrous Aconitum species (Delphinieae, Ranunculaceae). Flora 209(9): 464-470. DOl: 10.1016/j.flога.2014.07.001 


\section{Ј. APPC. SCL. VOL. 58 N NO. 220014}

Balfour N., Garbuzov M., Ratnicks F. L. W. (2013) Longer tongues and swifter handling: why do more bumble bees (Bombus spp.) than honey bees (Apis mellifera) forage on lavender (Lavandula spp.)? Ecological Entomology 38: 323-329. DOl: 10.1111/een.12019

Cane J. H. (2001) Habitat fragmentation and native bees: a premature verdict? Conservation Ecology 5(1). Available at: http://www.consecol.org/vol5/iss 1/art3/

Carlson J. E., Harms K. E. (2006) The evolution of gender-biased nectar production in hermaphroditic plants. The Botanical Review 72: 179-205. DOl: $\quad$ 10.1663/0006-8101(2006)72\%5B179:TEOGNP $\% 5$ D2.0.CO;2

Czarnecka B., Denisow B. (2014) Floral biology of Senecio macrophyllus M. Bieb. (Asteraceae), a rare Central European steppe plant. Acta Societatis Botanicorum Polonie $83(1):$ 17-27.

Delaplane K. S., Mayer D. F. (2000) Crop pollination by bees. CABI Publishing. New York. 7-84. DOl: 10.1079/9780851994482.0000

Denisow B. (2006) Blooming biology and pollen abundance of some Centaurea sp. Journal of Apicultural Science 50(2): 20-31.

Denisow B. (2009) Factors determining diurnal dynamics of blooming of chosen plants species. Acta Agrobotanica 62(1): 83-89. DOl: 10.5586/aa.2009.010

Denisow B. (201 1) Pollen production of selected ruderal plant species in the Lublin area. Univ. Life Sci. Press. Lublin. 86 pp.

Denisow B., Bożek M. (2006) Biologia kwitnienia i obfitość pylenia Anemone japonica Houtt. = Anemone $x$ hybrida hort. Acta Agrobotanica 59(1): 139-146. DOl: 10.5586/ aa/2006.014

Denisow B., Strzałkowska-Abramek M. (2013) Characteristics of blooming and pollen in flowers of two Syringa species (f. Oleaceae). Acta Agrobotanica 66: 65-72. DOl: 10.5586./aa.2013.0520

Erdtman G. (1954) An introduction to pollen analysis Chronica Botanica Company. Waltham, Massachusetts, USA. 239 pp.
Fajerski M. Rozwój ogrodnictwa w Polsce. Biznes Ogrodniczy. Available at: http://www.biznes-ogrodniczy.pl/pl/ raport/rozwoj_ogrodnictwa_w_polsce.html

Fussell M., Corbet S. A. (1 992) Flower usage by bumblebees: a basis for forage plant management. Journal of Applied Ecology 29: 451-465. DOl: 10.2307/2404513

Garbuzov M., Ratnieks F. W. L. (2013) Quantifying variation among garden plants in attractiveness to bees and other flower-visiting insects. Functional Ecology 28:364-374. DOl: 10.1111/1365-2435.12178

Goulson D. (1999) Foraging strategies of insects for gathering nectar and pollen, and implications for plant ecology and evolution. Perspectves in Plant Ecology, Evolution and Systematics 2(2): 185-209. DOl: 10.1078/14338319-00070

Goulson D., Lepais O., O'Connor S., Osborne J., Sanderson R. A., Cussans J. (2010) Effect of land use at a landscape scale on bumblebee nest density and survival. Journal of Applied Ecology 47: 1207-1215. DOI: 10.1111/j.13652664.2010.01872.x

Jabłoński B., Szklanowska K. (1997) Wpływ niektórych czynników pogody na kwitnienie, nektarowanie, pylenie i oblot przez owady entomofilnych roślin uprawnych.In: Biologia kwitnienia, nektarowania i zapylania roślin. 1 Ogólnopolska Konferencja Naukowa. Lublin - Poland. 1314 November 1997: 53-58.

Jafari E., Ghaubarian G. H. (2007) Pollen morphological studies on selected taxa of Asteraceae. Journal of Plant Sciences 2(2):195-201. DOl: 10.3923/ jps.2007.195.201

Kearns C. A., Inouye D. W., Waser N. M. (1998) Endangered mutualisms: the conservation of plant-pollinator interactions. Annual Review of Ecology and Systematics 29:83-112. DOl: 10.1146/annurev.ecolsys.29.1.83

Klein A. M., Vaissiere B. E., Cane J. H., Steffan - Dewenter I., Cunningham S. A., Kremen C., Tscharntke T. (2007) Importance of pollinators in chanching landscapes for world crops. Proceedings of the Royal Society B 274: 303313. DOl: 10.1098/rspb.2006.3721

Kołtowski Z. (2006) Wielki atlas roślin miododajnych. Przedsiębiorstwo Wydawnicze Rzeczpospolita. Warszawa. 327 pp. 
Lipiński M. (2010) Pożytki pszczele. Zapylanie i miododajność roślin. Państwowe Wydawnictwo Rolnicze i Leśne. Warszawa. 320 pp.

Marcinkowski J. (2002) Byliny ogrodowe. Państwowe Wydawnictwo Rolnicze i Leśne. Warszawa. 419 pp.

Masierowska M. (2012) Floral phenology, floral rewards and insect visitation in an ornamental species Geranium platypetalum Fisch. \& C. A. Mey., Geraniaceae. Acta Agrobotanica 65(2): 23-36.

Müller A., Diener S., Schnyder S., Stutz K., Sedivy C., Dorn S. (2006) Quantitative pollen requirements of solitary bees: implications for bee conservation and the evolution of bee-flower relationships. Biological Conservation 130: 604-615. DOl:10.1016/j.biocon.2006.01.023

Petanidou T., Vokou D. (1990) Pollination and pollen energetics in Mediterranean ecosystems. American Journal of Botany 77: 986-992. DOl: 10.2307/2444569

Pohl N. B., Van Wyk J., Campbell D. R. (201 1) Butterflies show flower colour preferences but not constancy in foraging at four plant species. Ecological Entomology 36(3): 290-300. DOl: $10.1111 / j .1365-2311.2011 .01271 . x$

Roulston T. H., Cane J. H., Buchmann S. L. (2000) What governs protein content of pollen: pollinator preferences, pollen-pistil interactions, or phylogeny? Ecological Monographs 70: 617-643. DOl: 10.2307/2657188

Schlindwein C., Wittmann D., Martins C. F., Hamm A., Siqueira J. A., Schiffler D., Machado I. C. (2005) Pollination of Campanula rapunculus L. (Campanulaceae): How much pollen flows into pollination and into reproduction of oligolectic pollinators? Plant Systematics and Evolution 250: 147-156. DOl: 10.1007/s00606-004-0246-8

Ssymank A., Kearns C. A., Pape T., Thompson F. C. (2008) Pollinating flies (Diptera): A major contribution to plant diversity and agricultural production. Biodiversity 9(1-2) 86-89. DOl: 10.1080/14888386.2008.9712892

Stanisz A. (1996) Przystępny kurs statystyki z zastosowaniem STATISTICA PL na przykładach z medycyny. Statsoft Polska. Kraków. 359 pp.
Statistica ver. 6.0. StatSoft Poland, Krakow.

Strzałkowska M. (2006) Kwitnienie i wartość pożytkowa Solidago hybrida hort. Annales Universitatis Mariae Curie-Skłodowska. Sectio EEE: Horticultura 6: 131-137.

Szklanowska K., Denisow B. (1999) Pożytek pyłkowy z dziewanny (Verbascum L.), dziurawca (Hypericum L.) i wiązówki (Filipendula (L.) Max.). Annales Universitatis Mariae Curie-Skłodowska. Sectio EEE: Horticultura 7: 6370.

Wróblewska A., Magacz Z. (2006) Wartość pszczelarska Zinnia elegans Jacq. In: Materiały XLIII Naukowej Konferencji Pszczelarskiej. Puławy - Polska. 5-27 kwietnia: 197-199.

Wróblewska A., Stawiarz E. (201 1) Flowering abundance and pollen productivity of Ligularia clivorum Maxim. and Ligularia przewalskii Maxim. Acta Scientarum Polonorum, Hortorum Cultus 11 (3): 57-67.

Wrzesień M., Denisow B. (2006) The usable taxons in spontaneous flora of railway areas of the central-eastern part of Poland. Acta Agrobotanica 59(2): 95-108. DOl: 10.5586/aa.2006.065

Wrzesień M., Denisow B. (2007) The phytocoenoses of anthropogenically transformed areas with a great importance for Apoidea. Acta Agrobotanica 60(2): 1 17-126. DOl: $10.5586 /$ a..2007.039

Zych M. (2007) On flower visitors and true pollinators: The case of protandrous Heracleum sphondylium L. (Apiaceae). Plant Systematics and Evolution 263: 159179. DOl: 10.1007/s00606-006-0493-y

Zych M., Stpiczyńska M. (2012) Neither protogynous nor obligatory out-crossed: pollination biology and breeding system of the European Red List Fritillaria meleagris L. (Liliaceae). Plant Biology 14: 285-294. DOl: $10.1111 / j .1438-8677.2011 .00510 . x$ 